
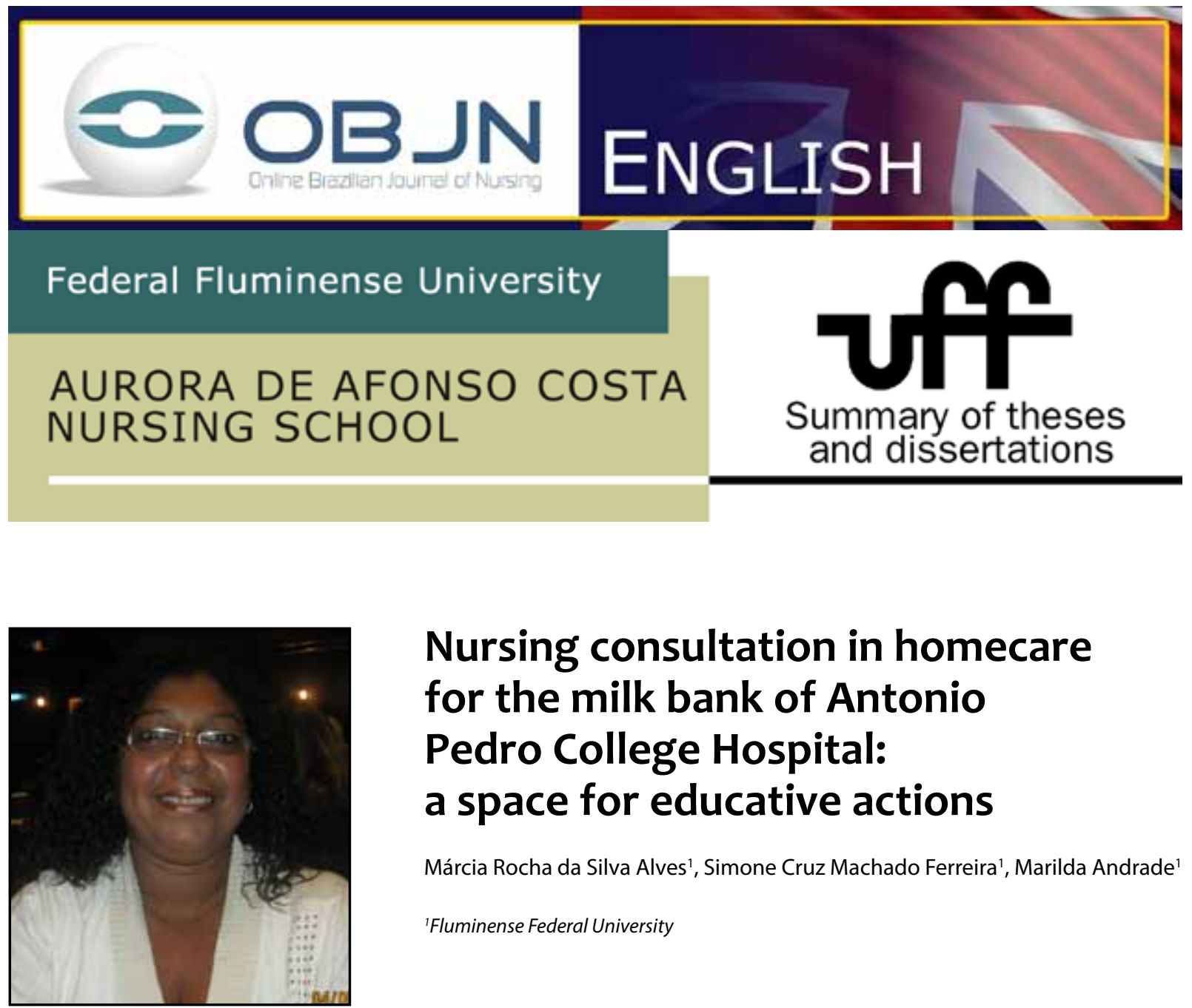

\title{
Nursing consultation in homecare for the milk bank of Antonio Pedro College Hospital: a space for educative actions
}

Márcia Rocha da Silva Alves', Simone Cruz Machado Ferreira', Marilda Andrade ${ }^{1}$

'Fluminense Federal University

\section{ABSTRACT}

Aim: To develop a standard instrument for nursing consultations with regard to homecare; to characterize the consultations in homecare, to establish its articulation with educational activities performed by the nurse and; to analyze the practice of this consultation, considering the point-of-view of the donor woman. Method: This is a descriptive research which adopts a qualitative approach. It was based on the scenario of a human breast milk bank at Antonio Pedro College Hospital in Niterói, Brazil. 22 women were interviewed which involved answering a semi-structured questionnaire. The data were grouped into two categories.

Results: Analytical categories: home visits and the educative practice of the nurse; the home nursing consultation from the perspective of the nurturing woman. A standard instrument for nursing consultations was produced. Conclusion: The educational actions of the nurse during homecare have three main focuses: the motivation to breastfeed, the necessary caring for the baby and the mother, and the safe procedure when it comes to collecting human milk.

Descriptors: Nursing; Milk Banks; Home Visit; Health Education. 


\section{INTRODUCTION}

The lack of understanding with regard to the practice in breastfeeding is only seen during breastfeeding itself and has, is a consequence, the origins of doubts, fears, anguish and insecurity. However, the nurse can be a facilitator in this process, helping the nurturing woman with scientific and practical knowledge, establishing a relationship of mutual help and an exchange of experiences with regard to this subject.

Thus, to perform nursing consultation in the home of the donor woman means offering direct assistance to the individual, to the family and to the community, in a systematic and continuous way, with the objective of promoting health through early diagnosis and treatment, portraying the educational actions performed by the nurse and determining how this professional must act ${ }^{(1)}$.

Engaging in nursing consultation means providing integral care to the child, to the mother, to the family and to society. It goes beyond any complications, considers the educational aspects, and permits early prevention of any health problems ${ }^{(2)}$.

Homecare is understood as an opportunity for educational actions performed by the nurses of the Human Milk Bank of Antonio Pedro College Hospital (BLH/HUAP, in Portuguese), which materialized through the nursing consultation. Such consultation is intended to search for, guide and clear doubts regarding breastfeeding, to lead to a self-evaluation of the nurturing mother and her baby, and to collect any excess milk. As this process is not simply that related to the binomial mother-son relationship, any relatives present must be encourage to participate, sharing the experience with the woman.

\section{AIMS}

To develop a standard instrument based on technical-scientific information with a strategy for nursing consultations in the patient's home; to characterize nursing consultation during homecare, establishing its articulation with the educational activities developed by the BLH/HUAP nurses and; to analyze the performance of the nursing consultation done in homecare, considering the point-of-view of the donor woman, and to elaborate a standardized technical-scientific instrument.

\section{METHOD}

This is a descriptive research based on a case study, using a qualitative approach ${ }^{(3)}$. The scenario of the study was the BLH/HUAP, with regard to which homecare is an institutionalized practice. It specializes in the promotion of breastfeeding and human milk collection, using as a strategy the orientations of the nurse during homecare visits. Therefore, the interviews were performed in the homes of the nurturing women, taking advantage of the nursing consultation performed during homecare. The subjects of this study were 22 women enrolled in the system, interviewed between January and October 2012. To identify the interviewees, this research used the pseudonym "Maria" (Mary, in English), mother of Jesus, an example of a donating mother. The research was approved by the Ethics in Research Committee, under register CAAE 0308.0.258.000.111.

\section{RESULTS}

The study presents two analytical categories: homecare and the educational practice of 
the nurse and nursing consultation in homecare from the perspective of the nurturing woman. Summarizing, these categories refer to the educational activities performed by the nurse at the homes of the interviewed women, and their importance as declared by these participants. The reflections of this study resulted in a guiding manual for nursing consultations, which will enable a better approach with regard to providing orientation to the nurturing woman at her home.

\section{CONCLUSION}

Homecare is a strategy used by the nurses of the human milk bank to emphasize the nursing consultation, and to assist the educative practice. Such content has three main axes: the motivation to breastfeed, the necessary care of the baby and of the mother, and the collection of excess human milk to take as much advantage as possible of this product.

Therefore, the implemented educational activities performed by the nurse at the home of nurturing women follow a sequence designed for nursing consultation. However, from the evaluation performed during the consultation, it acquires specificities that respond to the new necessities that emerged. On reflection, it is seen that there are women who need further information regarding breastfeeding, holding the baby and caring for their breasts/nipples, while others have a complete lack of information regarding the procedures involved in collecting and saving milk. There are also those who are afraid of not being able to take care of their babies because they don't know what do and what their babies may need. Consequently, such women may be afraid that they cannot correctly carry out their roles as mothers.

\section{REFRERENCES}

1. Carvalho SC, Silva CP. Reflexo da Sistematização da Assistência de Enfermagem (SAE) na Consulta de Enfermagem. Revista Rede de Cuidados em Saúde [Internet]. 2008 [cited 2013 Sept 6]; 2 (2): [about 5 p.]. Available from: http://publicacoes. unigranrio.edu.br/index.php/rcs/article/viewFile/91/101

2. Kalinowski LC, Favero L, Carraro TE, Wall ML, Lacerda MR. Postpartum primipara at home and associated nursing care: Grounded Theory. Online braz j nurs [Internet]. 2012 Nov [cited 2013 Sept 7]; 11 (3): 701-19. Available from: http://www. objnursing.uff.br/index.php/nursing/article/ view/3852. doi: http://dx.doi.org/10.5935/16764285.20120046

3. Figueiredo, NMA. Método e Metodologia na Pesquisa Científica. 2. ed. São Caetano do Sul: Yendis; 2007.

Place, Date of Dissertation Defense: Rio de Janeiro, Brazil. December $21^{\text {st }} 2012$.

Examiners: Prof. Dr. Marilda Andrade (President of the Examination Board); Eng. Dr. Danielle Aparecida da Silva (Examiner); Prof. Dr. Simone Cruz Machado Ferreira (Examiner).

Reference: Alves MRS. A consulta de enfermagem na visita domiciliar do banco de leite humano do Hospital Universitário Antônio Pedro: um espaço de ações educativas. Niterói. Dissertação [Mestrado em Enfermagem] - Universidade Federal Fluminense; 2012.

Received: 30/08/2013

Revised: 05/09/2013

Approved: 07/09/2013 